\title{
Innovative Technologies for Construction of Rural Road Pavements using Local Resources
}

\author{
Adarsh Kumar Tiwari, Shashwat Nagar, A.K.Shukla
}

\begin{abstract}
Connectivity in rural areas is a key aspect of its holistic development. Rural roads are low traffic volume roads. In this paper, study has been done on the construction methodology of rural roads using local resources i.e., local labour, local materials etc. Locally available stones, cobbles, plum etc. have been used with concrete mix. This study throws light on three types of rigid pavements which follow the evolution of Roman road construction methods. These are Cobblestone pavements (CSPs), Plum Concrete pavements (PCPs) and Un-reinforced Concrete pavements (UCPs). This paper discuss about the materials used and the construction methodology of all these three types of rigid pavement. The paper also presents an outline of locally available materials which helps in reducing the overall cost of construction of pavements.
\end{abstract}

Keywords- Cobblestone pavements, Local Resources, Plum Concrete pavements, Un-reinforced Concrete pavements

\section{INTRODUCTION}

As per Basic Road Statistics of India 2016-2017, rural roads account for $70.65 \%$ of the total road length in India. The length of rural road network is 41.67 lakh km. Further, rural areas account for $68.84 \%$ of India's population (Census 2011). Therefore by improving rural road connectivity, economic growth of the country can be improved.

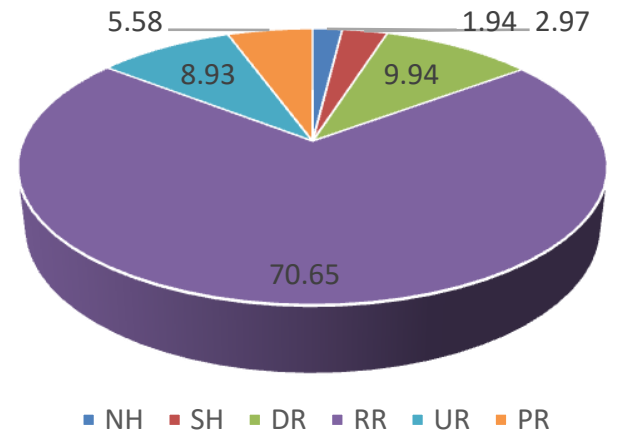

Fig.1 India's Road Network

(Source: Basic Road Statistics of India 2016-2017)

For people residing in rural areas rural connectivity becomes a critical issue for the social and economic development. The condition of rural people can be changed by investing in rural roads construction. It can be seen that there is unequal development of the rural road network in the country.

Revised Manuscript Received on June 30, 2020.

* Correspondence Author

Adarsh Kumar Tiwari*, Civil Engineering Department, IET Lucknow, India. Email: adarshkrtiwari@gmail.com

Shashwat Nagar, Civil Engineering Department, IET Lucknow, India. Email: shashwat1560.11@bitmesra.ac.in

A. K. Shukla, Civil Engineering Department, IET Lucknow, India. Email: arvind.shukla@ietlucknow.ac.in

(C) The Authors. Published by Blue Eyes Intelligence Engineering and Sciences Publication (BEIESP). This is an open access article under the CC BY-NC-ND license (http://creativecommons.org/licenses/by-nc-nd/4.0/)
Problems of insufficient funds for construction, maintenance and rehabilitation of existing rural roads are the bigger task. Therefore, there is need of innovative methodology for the construction of rural roads which is cost-effective. This can be achieved by utilising various locally available materials, labours etc. Local resources can be human resources, local government, NGO and community institutions, locally made or fabricated hand tools or intermediate equipment, local materials such as locally produced aggregates, timber and other materials or inputs.

\section{TYPES OF PAVEMENT}

a) Cobblestone pavements (CSPs),

b) Plum Concrete pavements (PCPs) and

c) Un-reinforced Concrete pavements (UCPs)

\section{CONSTRUCTION OF COBBLESTONE PAVEMENTS}

This type of pavement is used for rural road construction where rock material is easily available. Further this road is suitable for medium to high traffic densities. It is also suitable for steep longitudinal gradient road. For stone surfacing natural shape of stone is used and it is placed manually so that one can achieve minimum voids in between the stones. For this purpose the size of joint is kept minimum.

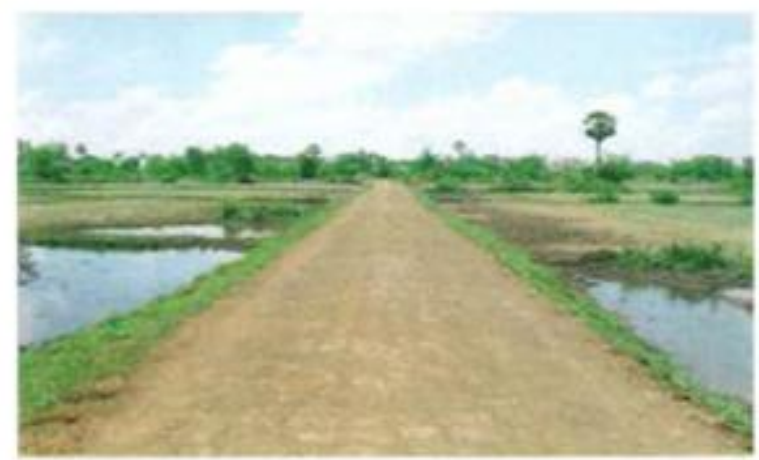

Fig. 2 Cobblestone Pavement

(Source: Manual Pavement-Labour Based Technology for Rural Road Works)

A. Materials used in construction

i) Stones

The stone that has to be used in construction of pavement must be durable, hard, clean, and free from loose materials. Stones which are cracked and hollow sections should not be used in construction of pavement. Generally cubical or rectangular stones are used.

Published By:

Blue Eyes Intelligence Engineering 
Table-I: Specifications of stone to be used in construction of stone surfacing

\begin{tabular}{|l|l|l|}
\hline S.No. & Type of Work & Specifications \\
\hline 1 & For Filling Gaps & $2 \mathrm{~cm} \times 3 \mathrm{~cm}$ and $3 \mathrm{~cm} \mathrm{\times} 5 \mathrm{~cm}$ \\
\hline 2 & For surfacing & $\begin{array}{l}15 \mathrm{~cm} \times 25 \mathrm{~cm} \\
10 \mathrm{~cm} \times 15 \mathrm{~cm} \\
\text { (minimum acceptable size) }\end{array}$ \\
\hline 3 & For edge kerb & $\begin{array}{l}20 \mathrm{~cm} \times 30 \mathrm{~cm} \\
15 \mathrm{~cm} \times 25 \mathrm{~cm} \\
\text { (minimum acceptable size) }\end{array}$ \\
\hline
\end{tabular}

ii) Sand

The sand should be clean, dry free from grass, leaves, dust, compost etc. For this purpose coarse sand should be used which can be obtained from river or mountain sand.

\section{iii) Gravel}

The gravel should be clean which is free from grass, leaves, compost, clay lumps etc. The maximum size of gravel that is permitted is $50 \mathrm{~mm}$. For this purpose well graded gravel should be used which can be obtained from river or mountain gravel.

\section{B. Construction Procedure}

The construction of cobblestone pavement can be explained from the following flowchart.

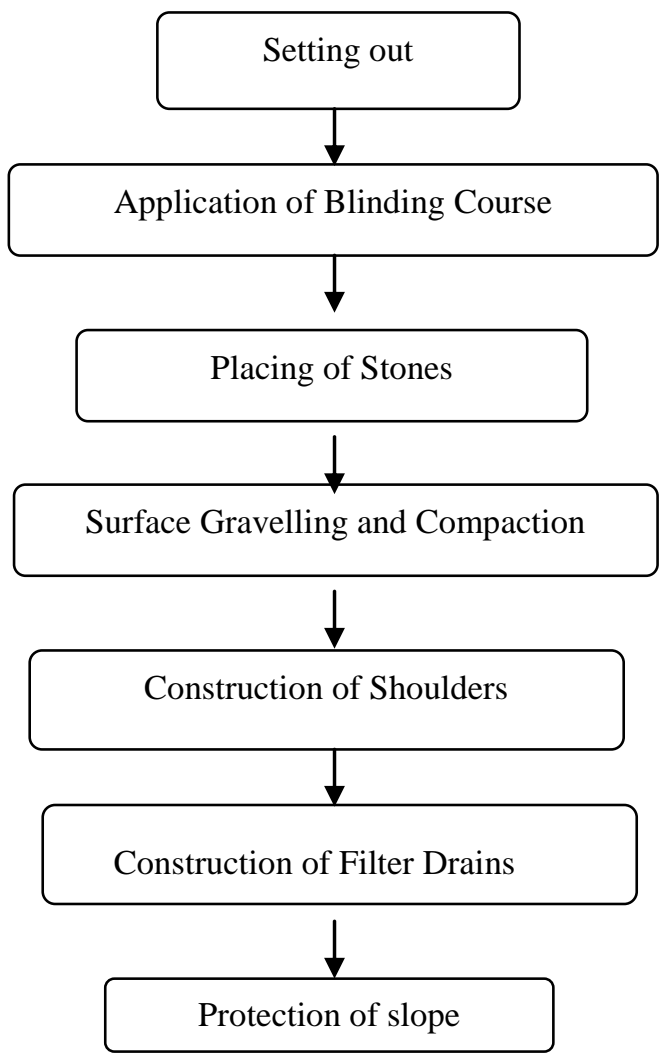

Fig. 3 Flowchart of construction methodology for cobblestone pavement

\section{i) Setting Out}

The road cross section is set at every $5 \mathrm{~m}$ interval. For this purpose use centre line peg and pegs at edges of carriageway. Mark the finished level of the stone surface at the middle line and transfer with the design cross-fall to edge pegs. The cross-fall from the middle line to the sting pegs should be $4-5 \%$.

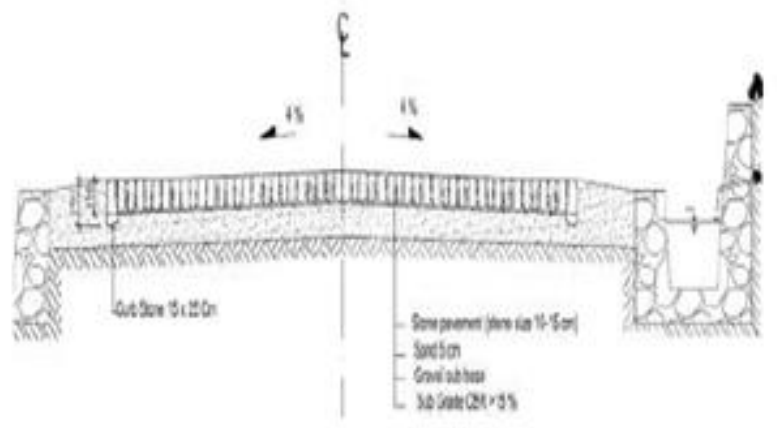

Fig. 4 Cross section of pavement

(Source: Manual Pavement-Labour Based Technology for Rural Road Works)

\section{ii) Application of Blinding Course}

First of all road sub base is prepared by changing its shape and ensuring camber of 4-5\%. After the preparation of sub base, compact it and then spread the blinding course layer of coarse sand of $5 \mathrm{~cm}$ thickness.

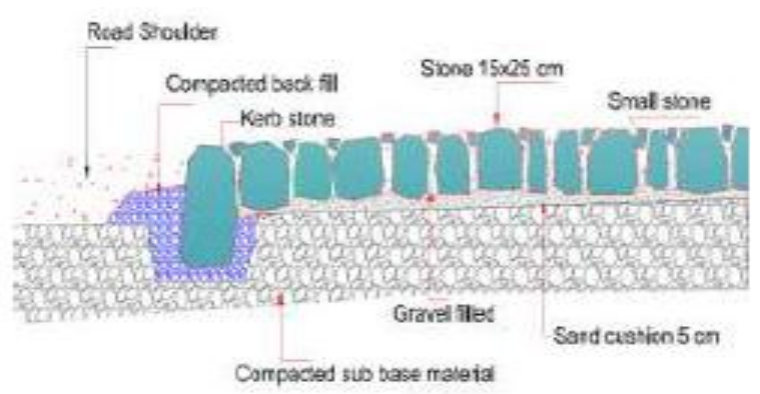

Fig. 5 Application of Blinding Course (Source: Manual Pavement-Labour Based Technology for Rural Road Works)

\section{iii) Placing of Stones}

The stones should be placed very close to each other such that minimum void is obtained. First the stones are placed at the outer edge of pavement then proceed towards centre line of road. For achieving the minimum voids, small sized stones are placed in between the gaps of large sized stones.

\section{iv) Surface Gravelling and Compaction}

To make the stone surface water impermeable and smooth for riding, a thin layer of selected gravel $(5 \mathrm{~cm})$ is constructed above previous layer. The selected gravel should contain mixture of coarse aggregate having size less than $50 \mathrm{~mm}$, sand and small portion of clay. Then compaction is carried out by 3-5 tonne roller. The compaction should be done in 2-3 passes. It should be note that use of vibration is avoided. The compaction should be done from outer edge towards centre line of road.

\section{v) Construction of Shoulders}

Either use mountain gravel or laterite for the construction of shoulders. The filled material is spread such that slope of $7-8 \%$ is obtained away from the road. Vibrating pedestrian roller or plate compactor should be used for the compaction of shoulder materials.

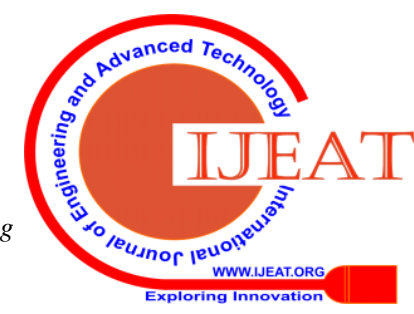




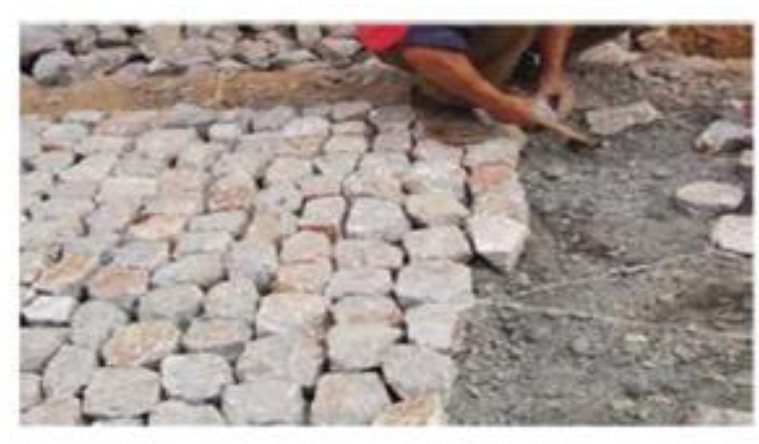

Fig. 6 Surface Gravelling

(Source: Manual Pavement-Labour Based Technology for Rural Road Works)

\section{vi) Construction of Filter Drains}

The construction of filter drains should be done by excavating the drain across the road shoulders while filling the road shoulders. The excavated box should be filled with broken stone and its surfacing should be done by the same material which has been used for construction of shoulders. The shape of drains should be rectangular having width 20 $30 \mathrm{~cm}$ with the invert of the drain similar to the bottom level of the kerbstone. Further, it should slope away from the road.

\section{vii) Protection of slope}

Plant grass for protecting the slope and shoulders from erosion. Where necessary bio-engineering work methods shall be engaged as required.

\section{CONSTRUCTION OF PLUM CONCRETE PAVEMENTS}

This type of surfacing should be used for rural roads where gravel surfacing is not suitable but may have steep longitudinal gradients. Further road should not have high traffic volumes. The plum concrete pavement is similar to ordinarily concrete pavement with the difference of inclusion of large solid stones. The volume of large solid stone is such that it reduces the volume of concrete needed by $30-40 \%$ but still provides a strong and durable pavement. Reduction in volume of concrete results in reduction in cost of pavement.

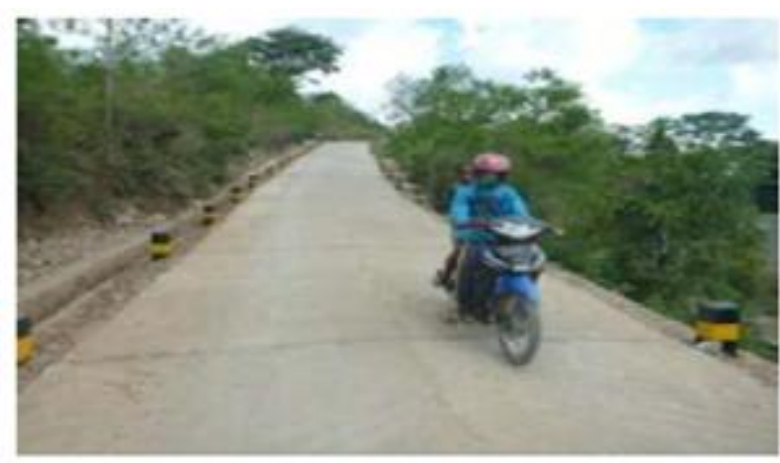

Fig. 7 Plum Concrete Pavement

(Source: Manual Pavement-Labour Based Technology for Rural Road Works)

\section{A. Materials used in construction}

ISSN: 2249 - 8958 (Online), Volume-9 Issue-5, June 2020

\section{i) Cement}

Use Ordinary Portland Cement (OPC) for this purpose. The cement used for this purpose is delivered in paper bags containing of $40 \mathrm{~kg}$ or $50 \mathrm{~kg}$ of cement in each. The cement should be stored in waterproof building which will protect it from dampness.

\section{ii) Aggregates}

The aggregate that has to be used in construction of pavement must be durable, hard, clean, and well graded. The maximum size of aggregate to be used in concrete is $50 \mathrm{~mm}$. The aggregates to be used can be crushed aggregate from stone or natural aggregate from river. There should not be large quantity of elongated, flaky and crushed particles.

iii) Sand

The sand should be clean, dry free from grass, leaves, dust, compost etc. For this purpose coarse sand should be used which can be obtained from river or mountain sand.

iv) Water

Avoid using water collected from sea water, surface runoff water, and dirty water with organic particle.

v) Plums

The properties of plums (large stones) should be same as that discussed in aggregate. Generally the size the large stones used for the plum concrete should be 7-10 $\mathrm{cm}$ and have a crushing strength of $100 \mathrm{~kg} / \mathrm{cm} 2$.

\section{B. Construction Procedure}

The plum concrete surface should be constructed in blocks. The length of the blocks should be 5 meter and width of the block should be half of the width of the road.

The construction of plum concrete pavement can be explained from the following flowchart.

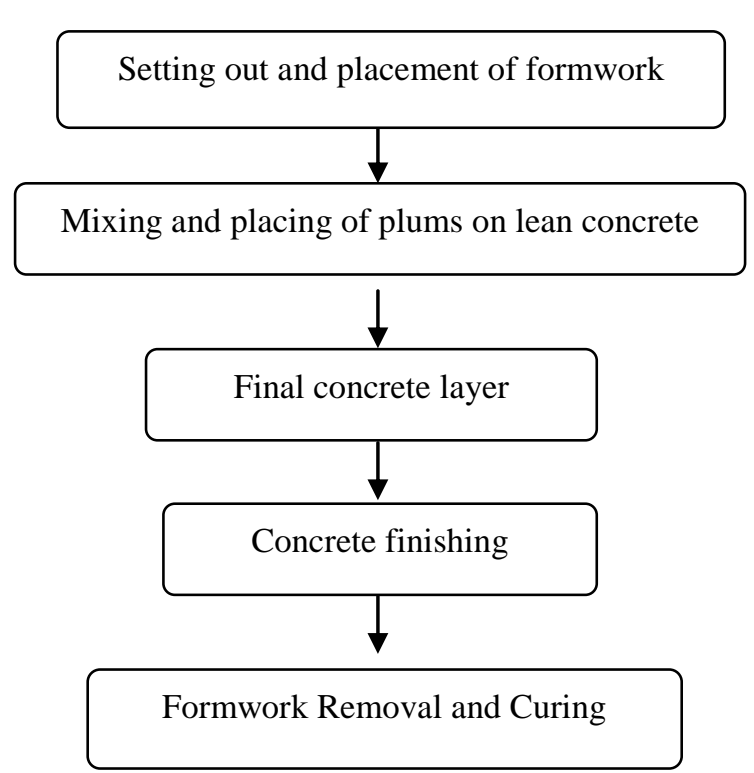

Fig. 8 Flowchart of construction methodology for plum concrete pavement

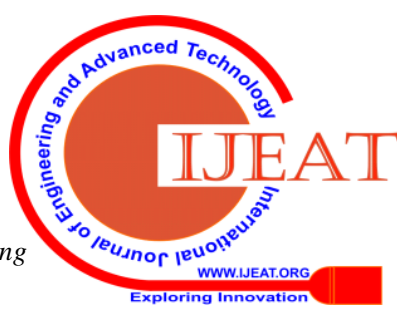




\section{Innovative Technologies for Construction of Rural Road Pavements using Local Resources}

\section{i) Setting out and placement of formwork:}

Fix the formwork in situ for half of road width. The dimension of box should be following:

- $\quad$ Width $=($ width of $\mathrm{road}) / 2$

- $\quad$ Length $=3-5 \mathrm{~m}$

The level should be higher at the centre line with respect to the edge support. There should be cross fall of 3\%. The boxes should be placed such that there should be a gap of 5$10 \mathrm{~mm}$ in between the boxes. This gap is used as expansion joint.

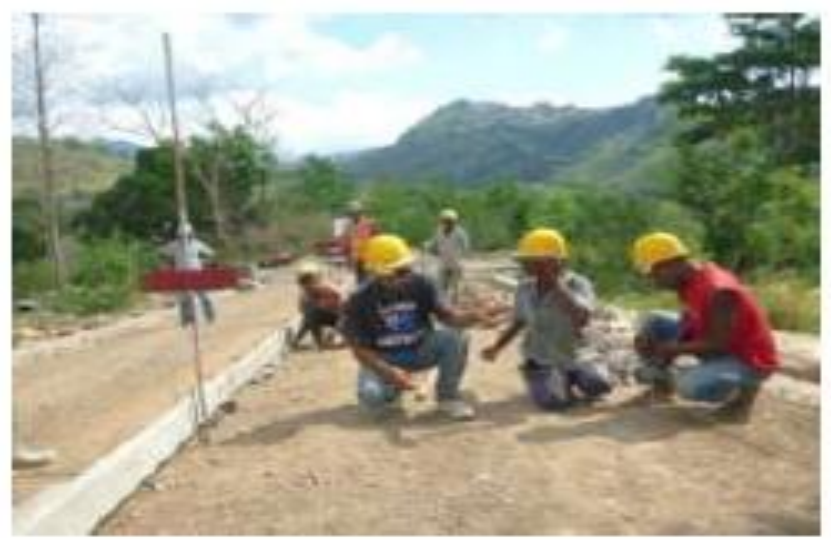

Fig. 9 Setting out and placement of formwork (Source: Manual Pavement-Labour Based Technology for Rural Road Works)

ii) Mixing and placing of plums on lean concrete:

The mixing of lean concrete should be done in concrete mixer as per the technical specifications. Generally 1:3:6 proportion is used for lean concrete with low water-cement ratio. As per the specifications, lean concrete should be laid at the designed thickness. (Generally the thickness of the lean concrete is $5 \mathrm{~cm}$ ).

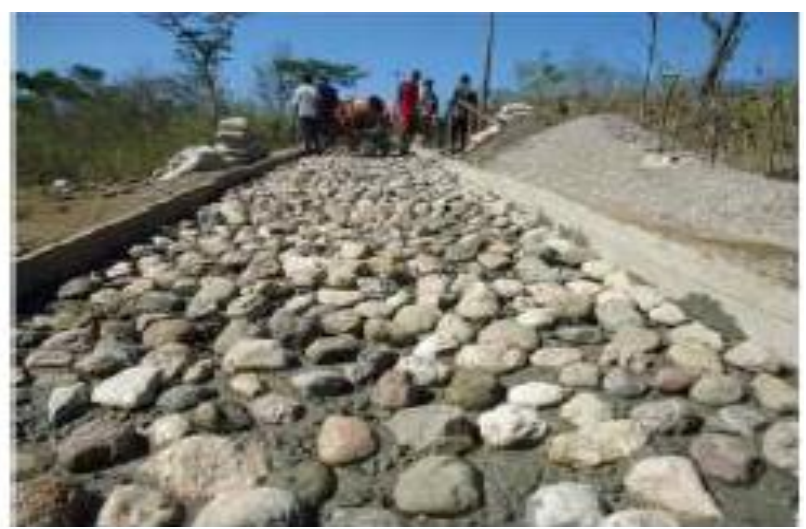

Fig. 10 Placing of Plums on Lean Concrete (Source: Manual Pavement-Labour Based Technology for Rural Road Works)

iii) Final concrete layer:

The pouring of concrete should be done such that there should be $2 \mathrm{~cm}$ cover over the top of stones. After pouring compaction should be done until all air is removed. The quantity of plums by volume shouldn't exceed $40 \%$ of the quantity of the finished concrete.

iv) Concrete finishing:
To achieve the desired surface profile as per specifications, the finishing should be done by aluminium screed board.

\section{v) Formwork Removal and Curing:}

Remove the formwork of concrete after 48 days which has been provided for edge support.

The curing of concrete should be done for minimum 7 days and preferably 14 days. It should start 3-4 hours after the placing of the concrete.

Following methods should be adopted for the curing of concrete:

- To keep the surface of concrete permanent wet, sprinkling of water can be done.

- Cover the concrete surface by wet jute, hessian mats or banana leaves.

- Cover the concrete surface with sand, sawdust (minimum $5 \mathrm{~cm}$ ) or empty cement bags. These covers should be kept continuously wet.

\section{CONSTRUCTION OF UN-REINFORCED CONCRETE PAVEMENTS (UCP)}

The construction of unreinforced concrete pavement is generally done in $4 \mathrm{~m}$ to $5 \mathrm{~m}$ long slabs. Depending upon the geometry of road or the ease of traffic diversions during construction, these slabs can be designed as full carriageway width or half width.

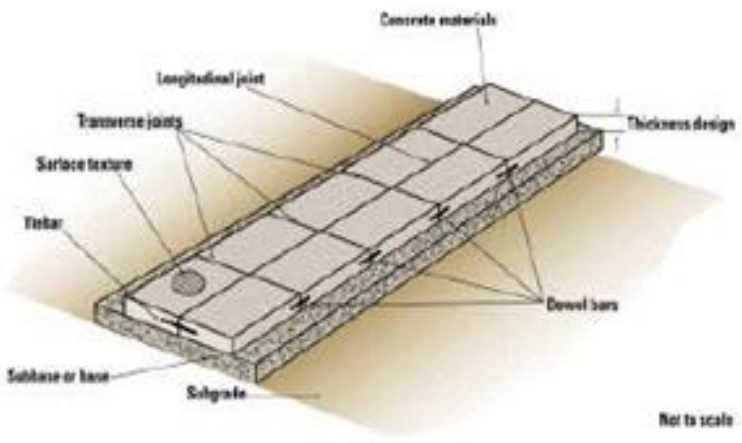

Fig. 11 Un-reinforced Concrete Pavements (UCP) (Source: Manual Pavement-Labour Based Technology for Rural Road Works)

\section{A. Materials used in construction}

Generally the concrete specified for un-reinforced concrete for rural road pavements involves concrete having minimum working strength of $20 \mathrm{MPa}$ (3000 PSI in 28 days), with minimum cement (OPC) content of $300 \mathrm{~kg} / \mathrm{M} 3$ and a maximum free water/cement ratio of 0.5.

\section{i) Cement}

Use Ordinary Portland Cement (OPC) for this purpose. The cement should be stored in waterproof building which will protect it from dampness.

\section{ii) Aggregate}

The aggregate that has to be used in construction of pavement must be durable, hard, clean, and well graded. There should not be large quantity of elongated, flaky and crushed particles. The aggregate should consist of crushed stone or gravel. The aggregate should contain




- $\quad<1 \%$ - material passing the $0.075 \mathrm{~mm}$

- $\quad<0.25 \%$ - clay lumps

- $\quad<3.5 \%$ - soft fragments

iii) Fine Aggregate/ Sand

The sand should be clean, dry free from grass, leaves, dust, compost etc. Natural sand, stone screening or other inert materials with similar properties can be used as fine aggregate/sand. The fine aggregate should contain

- $\quad<3 \%$ - material passing the $0.075 \mathrm{~mm}$

- $\quad<1 \%$ - clay lumps or shale

iv) Water

Water is required for mixing of concrete and curing of concrete. Sea water, surface run-off water, dirty water with organic particle must not be used.

\section{v) Admixtures}

The air entraining admixture should be used as per the specifications of AASHTO M 154. If chemical admixtures has to be used then it should fulfil the requirements of AASHTO M 194.

\section{vi) Curing Materials}

Following methods should be adopted for the curing of concrete:

- Cover the concrete surface by wet jute, hessian mats, banana leaves, water proof paper, white sheeting (film) materials etc. These covers should be kept continuously wet.

- $\quad$ A liquid membrane forming compound can be used as approved by the Engineer.

\section{B. Construction Procedure}

The construction of un-reinforced concrete pavement can be explained from the following flowchart.

i) Set-out and formwork placement:

The steel or timber formwork should be fixed in place to the designed height above the subgrade $(\sim 15 \mathrm{~cm}-10 \mathrm{~cm}$ pavement and $5 \mathrm{~cm}$ blinding course) and the level should be higher at the centre line with respect to the edge support. There should be cross fall of 3\%. For effective grade control it is also recommended that the slabs be constructed in an alternate pattern so enabling the initially unconstructed slabs to be accurately aligned with the already constructed slabs and to incorporate effective provision for expansion and slab connection and good grade control. Refer to the figure.

\begin{tabular}{|l|l|l|l|l|l|}
\hline Side 1 & 1 & 7 & 3 & 9 & 5 \\
\hline Side 2 & 6 & 2 & 8 & 4 & 10 \\
\hline
\end{tabular}

Fig. 12 Diagram showing sequence of construction of Pavement

(Source: Manual Pavement-Labour Based Technology for Rural Road Works)

ii) Formwork:

Formwork should be made of wood or metal. Before placing formwork, oiling should be done. It should remain in place for at least 48 hours after concrete placement.

\section{iii) Blinding/bedding course:}

Before the application of blinding course the sub grade or sub base should be prepared by rectifying the defects. After rectification apply the blinding layer of course sand or fines aggregate as specified shall be laid to a depth of $5 \mathrm{~cm}$, levelled and watered.

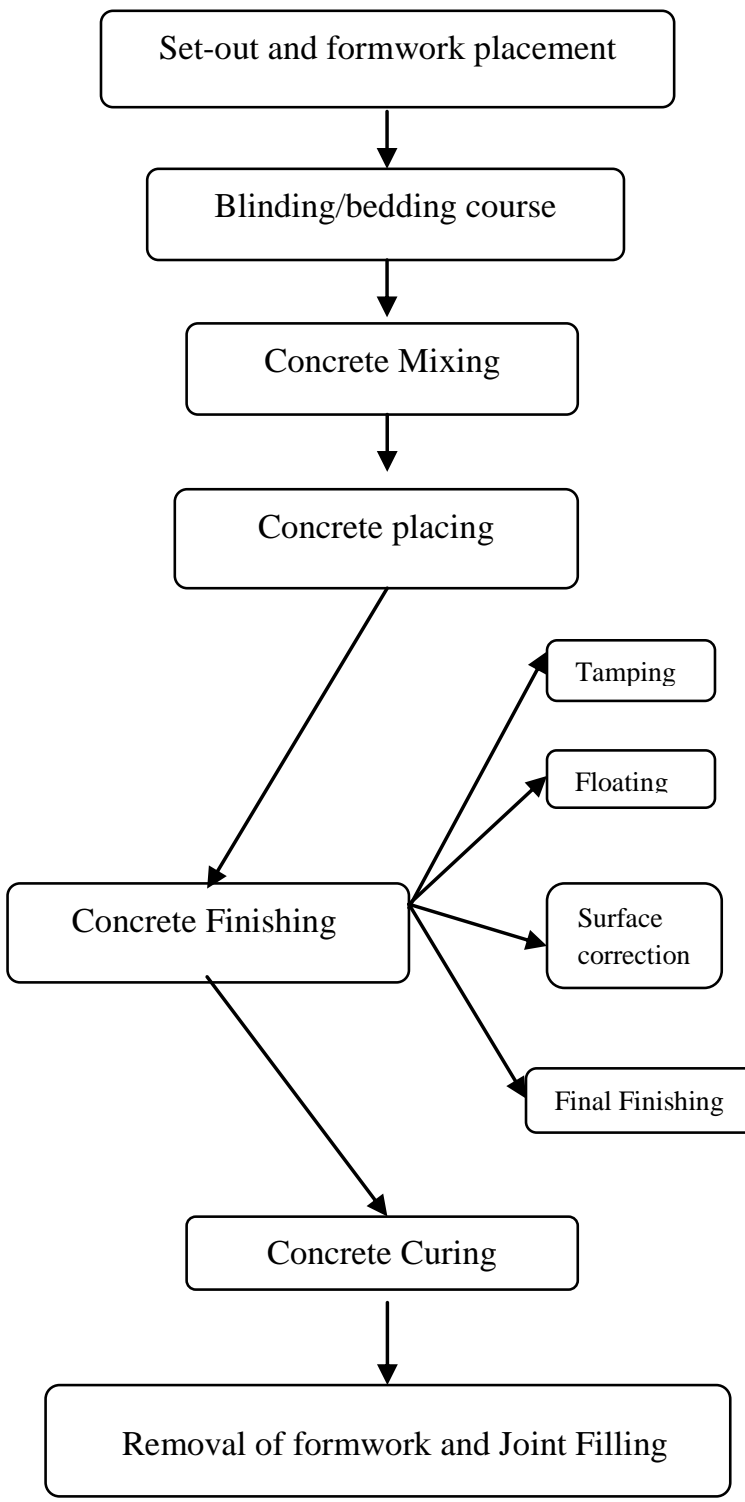

Fig. 13 Flowchart of construction methodology for unreinforced concrete pavement

\section{iv) Concrete Mixing:}

Power driven machine mixing of concrete is permitted. Hand mixing is not permitted. The mixing should be done for at least 3 minutes until the concrete is uniform in colour and desired consistency is achieved. Add the water before 25 percent of the mixing period has elapsed.

\section{v) Concrete placing:}

To avoid segregation of concrete it should be placed gently in position. The concrete should be placed from a height of $2 \mathrm{~m}$ or less. All concrete shall be hand spread with shovels and rakes within the formwork. Use immersion type vibrators for compaction of concrete.

\section{vi) Concrete Finishing:}

The finishing of concrete is done after placing of concrete. It consist of tamping, floating, surface correction and final finishing.

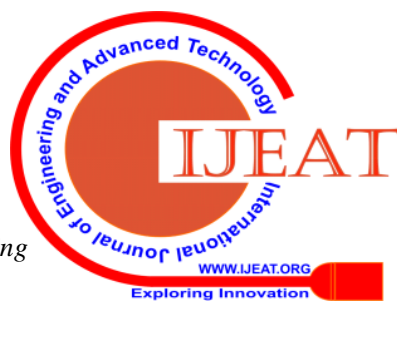




\section{Innovative Technologies for Construction of Rural Road Pavements using Local Resources}

\section{vii) Concrete Curing:}

Following methods should be adopted for the curing of concrete:

- $\quad$ Cover the concrete surface by wet jute, hessian mats, banana leaves, water proof paper, white sheeting (film) materials etc. These covers should be kept continuously wet.

- A liquid membrane forming compound can be used as approved by the Engineer.

- $\quad$ Cover the concrete surface with sand, sawdust (minimum 5 $\mathrm{cm}$ ) or empty cement bags. These covers should be kept continuously wet.



Fig. 14 Concrete curing

\section{(Source: Manual Pavement-Labour Based Technology for} Rural Road Works)

viii) Removal of formwork and Joint Filling:

Formwork should be removed after 48 hrs of concrete pouring. Joints shall be sealed with a flexible water-proof compound not long after finishing of the curing period and before the pavement is opened to traffic, including the Contractor's equipment.

\section{CONCLUSION}

This paper discuss about the innovative construction methodology of rural roads using local resources. Local resources can be human resources, local government, NGO, and community institutions, locally made or fabricated hand tools or intermediate equipment, local materials such as locally produced aggregates, timber and other materials or inputs. Therefore this technology can be termed as labour based technology for rural road works. As it uses local resources therefore the cost of construction is low. Further the construction procedure is also easy. There is no need of highly skilled labours. These type of pavements can be used for low traffic volume roads. Also, involving locally available labours, artisans etc. provide job opportunity in such areas.

\section{REFERENCES}

1. A Beusch et al 1997, Low Cost Road Construction in Indonesia. Labour Based Road Projects in Manggarai District, Intercooperation, Offsetdruck OD, Switzerland.

2. Basic Road Statistics of India, 2016-2017

3. Ethiopian Roads Authority, Pavement Design Manual Volume II, Chapter 4, Rigid Pavements - 2013

4. Guide for Design of Pavement Structures. American Association of State Highway and Transportation Officials (1993). AASHTO

5. Guide for Mechanistic-Empirical Design of New and Rehabilitated Pavements USA.(M-E PDG) (NCHRP 2004) Road Building in the Tropics: State-of-the- Art Review, TRL, No. 9. TRL, 1993.

6. Highways Department, Hong Kong, Research \& Development Division, Sept 2013, (RD/GN/017)

7. International Labour Office, Labour-Based Stone Paved Roads, Kampong Cham Province, Samer Al-Fayadl, ILO, Cambodia, 2001

8. Low volume concrete roads, Brian Perrie, Cement and Concrete Institute, South Africa

9. Manual Pavement Labour Based Technology for Rural Road Works, 2015.

10. Overseas Unit, Transport Research Laboratory, 1982, Overseas Road Note 3, A guide to surface dressing in tropical and sub-tropical countries, Crowthorne, Berkshire, United Kingdom.

11. P. N. Khanna (undated), Indian Practical Civil Engineer's Handbook, The Standard Every -Day Reference Book for all Engineers and Architects, India.

12. R. Dennis (undated), Handtools for Labour Based Roadwork, Guideline for selection and procurement, Mart Publication, United Kingdom.

\section{AUTHORS PROFILE}

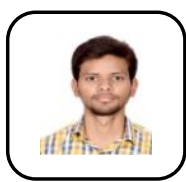

Publications:

Er. Adarsh Kumar Tiwari, B.Tech. in Civil Engineering from KNIT Sultanpur, M.Tech. in Transportation Engineering from MANIT Bhopal. He is a Professional Member of Institute for Engineering Research And Publication. He has secured Bronze medal in B.Tech.

Tiwari A.K., Shrivastava S, Singh K.,D Kishan., Evaluation of Strength Characteristics of Pavement Quality Concrete mixes Using Ekosoil International Research Journal of Engineering and Technology 2019; volume 6, DOI : e-ISSN:2395-0056.

Tiwari A.K., Shrivastava S, Singh K., A Study on Utilization of beneficiated Recycled Aggregate as a partial substitute of Natural Aggregate in Pavement Construction. International Conference on Recent Advancement in Transportation 2018; RAT/AHP/22

Shrivastava S, Tiwari A.K., Singh K., A Study on Strength Properties of Glass Fibre in concrete Using Pure Manufacturing Sand in place of Natura Sand and Fenugreek as Admixture. International Conference on Recent Advancement in Transportation 2018; RAT/AHP/21.

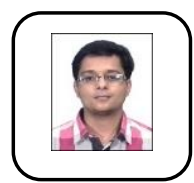

Er. Shashwat Nagar, B.E. in Civil Engineering from Birla Institute of Technology Mesra Ranchi, M.Tech. in Geotechnical Engineering from MANIT Bhopal. He is a Professional Member of Institute for Engineering Research And Publication.



Dr. A. K. Shukla, B.Tech. in Civil Engineering from GBPA\&T Pantnagar, M.Tech. in Traffic \& Transportation Engineering from IIT Kharagpur and $\mathrm{PhD}$ from AKTU. He is life member of Institute of Urban Transport (India), Indian Society for Technical Education,

Institution of Water \& Environment (India), Institution of

Engineers (India). He is editor of International Journal of Traffic \& Transport Engineering, (IJTTE) Belgrade

reviewer of Proceedings of the Institution of Civil Engineers SERBIA and

\section{Publications:}

- Shukla. Arvind. Kumar, Jain Sukhvir. Singh, Parida. Manoranjan. Srivastava. Jyoti. Bhutan. (2009) "Performance of FHWA model for prediction of traffic noise: A case study of metropolitan city, Lucknow (India)", TRANSPORT vol. 24, no. 3, 2009,pp. 234-240 Lithonia

- $\quad$ Shukla. A.K., Jain, S.S., Parida. M. and Srivastava. J.B. (2008) Performance of traffic noise models for metropolitan cities. International Journal Environmental Engineering and Management, Romania, ISSN: 1582-9596 ,Journal citation reports , Impact factor 1.435) vol.7, no.4, pp 447-452, July/August 2008

- Sudhanshu Bhushan, A.K.Shukla "Study Of Noise Pollution Level Using Noise Indices in the Study Of City Of Lucknow, Uttar Pradesh,India" International Conference on Engineering Technology, Science and Management Innovation(ICETSMI-2018).22 July ,2018,MCCIA,Pune.ISBN 978-93-87433-30-4.

- Ajay kumar Vasanwal, A.K.Shukla. "Study of Noise Exposure Leve (Annoyance) And Noise Parametre At Diwali Festival In Metropolitan City: 
Lucknow, India”International

EngineeringTechnology,Science

Conference Innovation(ICETSMI-2018).22 July ,2018, MCCIA ,Pune.ISBN 978 93-87433.

- $\quad$ Ankit kumar, Avneesh Tiwari, Tauqeer Alam, A. k. Shukla "Carbon Footprint of Solid Waste in Lucknow, India "International Journal of Technical Innovation in Modern Engineering and Science ( IJTIMES), ISSN: 24552585, March 2019

- $\quad$ Avneesh Tiwari, Tauqeer Alam, Ankit kumar, A. k. Shukla "Control of Odour, Volatile Organic Compounds (VOCs) \& Toxic Gases Through Bio-filtration An- Overview " International Journal of Technical Innovation in Modern Engineering and Science ( IJTIMES), ISSN: 24552585, March 2019

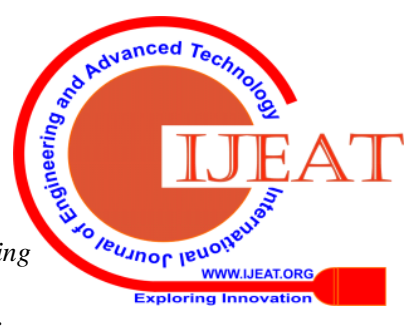

